\title{
An empirical study on entrepreneurial traits and their impact on enterprise success
}

\author{
Sthitaprajnya Pattanayak and Munindra Kakati \\ Department of Entrepreneurship and Management, \\ Assam Rajiv Gandhi University of Co-Operative Management (ARGUCOM), \\ Sivasagar, India
}

\begin{abstract}
Purpose - Enterprise success is driven by enterprise actions, which, in turn, is influenced by entrepreneurial behaviours. Behaviours are guided by traits. Hence, it is highly likely that personality traits of entrepreneur are critical to enterprise success. This paper aims at finding the relationship between entrepreneurial traits and enterprise success, identify underlying construct and examine how successful and unsuccessful entrepreneurs differ across traits. It also attempts enterprise profiling based on these traits and test predictive validity of entrepreneurial traits on enterprise success.
\end{abstract}

Design/methodology/approach - In this study, 396 micro, small and medium enterprises comprising both successful and unsuccessful ones are studied together across 11 personality traits. Data was analysed using various statistical techniques like co-relation, $t$-test, factor analysis, cluster analysis and regression to test hypothesis and arrive at given findings.

Findings - This study finds there is strong positive co-relations between traits and enterprise success. It establishes that successful and unsuccessful enterprises display distinct traits and significantly differ from each other. Entrepreneurial traits affect enterprise success, and the former has significant predictive value on the later $(\mathrm{R}$-squared $=0.866)$.

Practical implications - The findings have implications to entrepreneurs in relation to enriching the existing traits and inculcating new ones. Financial institutions like banks can peruse the findings and include traits and behavioural aspects in borrower selection, credit appraisal, evaluation and credit decisioning, to make it more holistic. It also generates scope for further academic research.

Originality/value - This study contributes to existing literature and validates existing findings. It also finds that traits are contagious in nature, together of which can be grouped to build an entrepreneurs' traits index which exerts strong influence on enterprise success.

Keywords Personality traits, Success factors, Small business, MSME, Behavioural traits, Enterprise success

Paper type Research paper

(c) Sthitaprajnya Pattanayak and Munindra Kakati. Published in Vilakshan - XIMB Journal of Management. Published by Emerald Publishing Limited. This article is published under the Creative Commons Attribution (CC BY 4.0) licence. Anyone may reproduce, distribute, translate and create derivative works of this article (for both commercial and non-commercial purposes), subject to full attribution to the original publication and authors. The full terms of this licence maybe seen at http:// creativecommons.org/licences/by/4.0/legalcode

Declaration: This is to declare that the authors have not received any funding, financial assistance or grants in relation to the present study.
Received 20 September 2021 Revised 30 October 2021 24 November 2021 Accepted 25 November 2021 


\section{Introduction}

Enterprise studies have emerged interdisciplinary, encompassing diversified branches of social sciences like economics, commerce, management and sociology. However, psychological approach to the discipline was lagging until 1990s. This was possibly because, researchers then believed, personality structure has less to do with business motives of entrepreneur, which was otherwise perceived to be predominately identified as maximising profit. Hence, it was believed that economic theories are only capable of explaining enterprise position (Brandstätter, 1997). Another possible reason might have been that, personality studies of the time were inconclusive due to confusing personality variables, unknown reliability and lack of theoretical justifications (Chandler and Lyon, 2001; Gartner, 1988). Therefore, some of the researchers even argued to the extent of abandoning future researches using traits paradigm (Chell, 1985; Gartner, 1988; Robinson et al., 1991).

However, renewed interests in the area were observed after Costa and McCrae (1992) came up with famous five factor model (FFM) of personality traits. FFM organised a vast varieties of traits into a small groups five meaningful constructs, read in acronym of OCEAN (Openness to experience, Conscientiousness, Extraversion, Agreeableness and Neuroticism). This explained broad human behaviours. It also helped researchers to analyse traits with respect to enterprise studies and derive meaningful relationships (Zhao and Seibert, 2006). Since then, there are numerous studies, which examined personality traits and entrepreneurship. However, most of them picked individual trait and analysed its impact on either success or failure. There are few studies, which, considered a set of traits and studied their impact on a mixed set of enterprises simultaneously to understand their relation, differentiating capabilities and predictive validity. The present study attempts to understand this using various statistical tools.

\section{Objective of study}

This study relates to micro, small and medium enterprises (MSMEs). MSMEs are important for economy but fragile in nature and vulnerable to quick failures. Beaver (2002) found, if anything is constant, it is the very high rates of failures among the small and young firms. While many enterprises succumb to failures, some of them survive and achieve phenomenal success. Beaver (2002) further argues, every business start-up is a unique event. Success factors and the circumstances to success are intangible and vary from entrepreneur to entrepreneur. It is difficult to identify because individual traits do not lend itself easily to measurability, replication and generalizability (Covin and Slevin, 1991). Researchers like, Caliendo et al. (2011) believed, intersection of psychology and economics holds strong prospects for conducting entrepreneurship research.

The study becomes more pertinent in the wake of substantial thrust on make-in-India concept, which rides significantly on the back of MSME performances. In India, MSMEs contribute about $45 \%$ of the total manufacturing output, $40 \%$ of the total exports and around $8 \%$ of the country's gross domestic product. They are the second largest employment generators after agriculture, providing employment to nearly 50 million people. There are about 63 million MSMEs, which account for nearly 90\% of industrial units (Source: www. makeinindia.com). Hence, the knowledge of effective entrepreneurial traits for enterprise success, which this study attempts to bring, becomes subject of further vital interest.

In the above background, present study aims to find:

- personality traits and their relationship with enterprise success;

- if there exists any difference between successful entrepreneurs and not-sosuccessful ones in terms of personality traits; 
- do these traits measure any underlying construct for successful and unsuccessful enterprises?; and

Empirical

study on

- do these traits have discriminating capability for grouping successful and not-sosuccessful enterprises? Do successful entrepreneurs pose similar traits and so do the unsuccessful ones?

entrepreneurial traits

\section{Literature review and conceptual framework}

\subsection{Personality traits}

Personality traits are set of stable pattern of behaviours through which a person can be described and identified with. This includes his thoughts and emotions, which influence the behaviours (McCrae and Costa, 2003). Earliest definitions of entrepreneur also identified it through traits. In 1755, Frenchman Cantillon defined entrepreneur as an individual with "foresight and ingenuity," who is eager to "accept the uncertainty" within the framework of economic market, and actively "pursue the profit” (Küçük, 2005). Similarly, Schumpeter's (1934) defined entrepreneur as a "visionary" and an "innovator," who goes for creative destruction of existing combinations and makes new combination by way of a new product, process or a new market.

Traits are descriptive variables, which are capable of describing how an individual think and behave (Parks-Leduc et al., 2014). Entrepreneurial behaviours are reflected in entrepreneurial actions. Bayarçelik and Özşahin (2014) termed it as entrepreneurial orientation (EO). Lumpkin and Dess (1996) called in leadership style.

Epstein and O'Brien (1985) argued, while the FFM explained aggregated constructs of human behaviour, they may not be capable of predicting specific behaviours like that of an entrepreneur. Hence, it is likely that predictive validity of FFM may be low in entrepreneurship research (Rauch and Frese, 2007). Therefore, better proximal constructs related to the tasks of entrepreneurs should be used (Baum and Locke, 2004).

Researchers like Miller (1983) and Lumpkin and Dess (1996) analysed it from the context of EO and concluded with five dimensions: pro-activeness, risk taking, innovation, autonomous and aggressive to competitor. Gull et al. (2021) concurred to this view and further extended the role of $\mathrm{EO}$ as enabler for global performance of firms and termed them international EO (IEO).

As such, entrepreneurial traits, behavioural aspects and leadership style are three distinct concepts. However, when it comes to enterprise study, they share certain common underlying objectives in their role as catalyst to enterprise success. Jaroliya and Gyanchandani (2021) argue that team performance is building block to achieve organisational goals and key variable for team performance is leadership style of team leaders. Performance of the group is largely reliant on authority style of the leader. When it comes to enterprise, entrepreneur is the first leader. Hence, it becomes pertinent to view the entrepreneurial traits from the lens of leadership traits also. In this regards, researchers have championed transformational leadership as tool for augmenting team performance. It is characterised by higher behavioural aspects like advanced thinking (Aragon-Correa et al., 2007), providing autonomy to employees, encouraging organisational learning and allowing creativity (Bass and Avolio, 1980, 1997; Gumusluoglu and Ilsev, 2009; Avolio, 1999; Judge and Piccolo, 2004). In a specific study Lather et al. (2009) found, leadership style boosts motivation and effectiveness of employees and certain leadership style play a role in dispute resolution process, thereby augmenting enterprise success.

Other researchers have also given emphasis to one or other specific trait like willing to bear risk (Say, 1971), ability to innovate (Subramaniam and Youndt, 2005; Boz and Ergeneli, 2014), 
eagerness for independence and competitive nature (Frese et al., 2002), need for achievement, locus of control and self-efficacy (Rauch and Frese, 2007; Kets de Vries, 1977; SchmittRodermund, 2004; Kumbul Guler and Tinar, 2009).

The above literature review is perused to shortlist a set of trait variables for the present study. Details of these are given in subsequent paragraphs.

\subsection{Micro small and medium enterprises}

As per the latest amendment to Micro Small and Medium Enterprises Development Act 2006 in July, 2020, Government of India defines MSMEs on the basis of combination of investment in plant and machineries and turnover, which is as given in Table 1.

Success. Success relates to the attainment of pre-decided goals and objectives. It is a multidimensional phenomenon having different forms such as; financial or non-financial, tangible or intangible, short term or long term. Bayarçelik and Özşahin (2014) argue that organisations have grown complex in their structures. Measuring success only through financial parameters is inadequate. It needs multidimensional measurement system which includes both subjective as well as objective measures. Therefore, Varadarajan and Ramanujam (1986) and Chittithaworn et al. (2011) suggested two-dimensional scheme covering both financial and operational indicators.

For the purpose of this study, "success" is being measured as a combination of both financial and non-financial parameters. Financial parameters considered are growth in sales revenue, profitability, indebtedness, sales realisation/receivable realisation and conduct of meeting external obligations. Non-financial parameters include achievement in terms of customer satisfaction, quality standard, brand building, employee satisfaction and selfsatisfaction. Respondents are asked to evaluate their business enterprise on these parameters on Likert scale of $1-5$ where 1 is the lowest and 5 is highest. Those scoring 25 or more are grouped in successful group and those scoring below 25 are placed in notsuccessful group.

\section{Research gap}

After review of literatures on previous studies, we observed, following are some of the research gaps, which the present study attempts to address.

- Most of previous studies analysed either a group of successful enterprises or a group of failed ones and identified traits influencing success or failure. Thus, findings from these studies came with their inbuilt limitations of generalizability, as they owed their origin either to successful group or to failed ones. Present study evaluates a set of successful and not-so-successful enterprise together across entrepreneurial traits.

- Even though certain influencing traits were identified, previous studies did not test the differentiating and discriminating capability of those traits. Here, an attempt is made to test this by enterprise profiling based on differentiating and discriminating

Table 1. Revised MSME classification

\begin{tabular}{llll}
\hline Classification & Micro & Small & Medium \\
\hline $\begin{array}{l}\text { Manufacturing and } \\
\text { services }\end{array}$ & $\begin{array}{l}\text { Investment }<\text { Rs 2 Cr, and } \\
\text { Turnover }<\text { Rs } 5 \mathrm{Cr}\end{array}$ & $\begin{array}{l}\text { Investment }<\mathrm{Rs} 10 \mathrm{Cr} \text { and } \\
\text { Turnover }<\mathrm{Rs} 50 \mathrm{Cr}\end{array}$ & $\begin{array}{l}\text { Investment }<\mathrm{Rs} 20 \mathrm{Cr} \text { and } \\
\text { Turnover }<\mathrm{Rs} 100 \mathrm{Cr}\end{array}$ \\
\hline
\end{tabular}


values of these traits and verify, if the traits, which worked for success were actually absent in unsuccessful ones and vice versa.

Empirical

study on

- Because most of previous studies focussed on either successful or failed group, the samples were picked up accordingly with prior information. Either all known successful samples or all known failed ones were studied. This often involved element of preferential biases, though unintended. All traits observed in successful ones were perceived to be good even if some of them might not be good and everything in unsuccessful ones were suspected to be bad even if some were not really bad. This study has attempted to eliminate this bias by taking combined group of enterprises and common set of traits.

\section{Research methodology}

\subsection{Methodology}

The present study is a descriptive research using primary data collected through selfadministered survey questionnaire and discussion. The subjects of study are MSME enterprises of Assam in North East of India. The region was selected for it offered mixed scope of challenges and opportunities. Challenges are geographical difficulties, connectivity issues, socio-political issues and limited resource availabilities. Opportunities are like strategic geo-position, Assam being gateway to entire North East, link to rest of India and other Eastern neighbouring countries (like Nepal, Bhutan and Bangladesh). Therefore, maximum development focus of Government and upbeat industrial activities are witnessed in the region in last decades.

As per Annual Report of Ministry of MSME, Government of India for Financial Year, 2020, there are 12.14 Lacs MSMEs in Assam, who constitute the population for this study. Out of this 396 samples were drawn which was well above the minimum sample size of 384 numbers, as verified from two separate sample adequacy calculators: Raosoft Sample Size Calculator (http://www.raosoft.com/samplesize.html) and Creative Research System (https:// www.surveysystem.com/sscalc.htm). A total of 550 samples were surveyed with selfadministered structured questionnaire. The data collection period was from 2018 to 2020 . Out of this, responses were received from 435 respondents. However, 39 responses were either incomplete or valid response was not there. Hence, finally 396 valid responses were received which is $72 \%$ and considered good.

\subsection{Personality traits considered for present research}

After going through the previous researches, related literature reviews and interactions with entrepreneurs, 11 items of personality traits were shortlisted as given in Table 2. Responses were obtained on these variables and the respondents were asked to score on a Likert scale of 1-5 representing strongly disagree to strongly agree, and this was followed by a discussion with the entrepreneurs

\subsection{Questionnaire design and reliability of the instrument}

The responses were obtained on a structured questionnaire, carrying three parts. Part A with eight items measured demographic variables, Part B contained 11 behavioral trait items as above and Part $\mathrm{C}$ measured success level of the enterprise through ten items. This included five financial items (like revenue, profit, indebtedness and sales/receivable realisations) and five non-financial items (like conduct of account, quality standard, brand building, level of customer satisfaction and self- satisfaction). Items are scored on Likert scale of 1-5. It has total peak score of 50. Enterprises, which scored 25 and above, are 
grouped as successful enterprise and those who scored below 25 are group as not-sosuccessful.

Reliability of the instrument was evaluated using the Cronbach's alpha $(\alpha)$ in SPSS. Alpha value of traits items and success parameters were 0.952 and 0.970 which is above 0.70 and considered good reliability (Zikmund et al., 2017).

\section{Data analysis, testing of hypothesis and discussion of results}

6.1 Relationship between personality traits and success

Spearman's rank co-relation test was conducted to understand relationship between personality traits and Enterprise success. For the purpose, the following hypothesis was tested.

H1. There is significant relationship between personality traits and success of an enterprise

The result suggests, there is strong positive co-relation between personality traits and success of an enterprise, $\rho(396)=0.911, p<0.000$, hence the hypothesis was accepted (Table 3).

\subsection{In terms of personality traits, do successful entrepreneurs differ from not-successful ones?}

To find, if all entrepreneurs display similar traits or they vary across the traits, the following hypothesis was tested.

\begin{tabular}{ll}
\hline PT1 & I like to experiment new ideas, new process even if it can potentially disrupt my business \\
& operation. (Risk taking) \\
PT2 & I encourage to find alternative ways to existing problems. (Innovative, creative) \\
PT3 & I encourage use of technologies in my business. (Acceptance to change) \\
PT4 & I like to introduce new product and process which I think it is going to be the future demand. \\
& (Innovative, risk taking, accepting changes) \\
PT5 & I like to be a trend setter in new product and process in my business. (First mover, innovative) \\
PT6 & I visualise how future changes are going to impact my business and prepare myself. \\
& (Farsighted, visionary, advance thinking, planning) \\
PT7 & I compare myself with my peers/competitors and try to outperform them. (Competitive) \\
PT8 & I always try to be the No. 1 in my field of business. (Aggressive) \\
PT9 & When people think of the top performers in my field, they take my name. (Competitive) \\
PT10 & I prefer to take a decision and avoid ambiguity. (Decisive, leading from front) \\
PT11 & I prefer to give clear instructions to my people in business as to what to do. (Decisive)
\end{tabular}

\section{Table 3.}

Spearman's rank correlations "personality traits and success"

\begin{tabular}{cllcr}
\hline & & & $\begin{array}{c}\text { Total of } \\
\text { PT_Scores }\end{array}$ & $\begin{array}{c}\text { Success parameter - } \\
\text { total score }\end{array}$ \\
\hline $\begin{array}{c}\text { Spearman's } \\
\text { rho }(\rho)\end{array}$ & Total of & Correlation coefficient & 1.000 & $0.911^{* *}$ \\
& PT scores & Sig. (two-tailed) & & 0.000 \\
& Success parameter - & Correlation coefficient & $0.911^{* *}$ & 396 \\
& total score & Sig. (two-tailed) & 0.000 & 1.000 \\
& $N$ & 396 & 396 \\
& & & &
\end{tabular}


H2. There is significant difference in the personality traits of successful entrepreneurs from not-successful entrepreneurs.

Empirical

study on

An independent $t$-test was conducted to compare successful group $(N=207, \mathrm{M}=43.03$ and $\mathrm{SD}=3.900)$ and not-successful ones $(N=189, \mathrm{M}=25.93$ and $\mathrm{SD}=4.864)$. Homoscedasticity condition was not met as Levene's test for equality of variances has come significant $(\phi=$ $0.012<0.05$ ). This is practical in a real world (Zikmund et al., 2017). There was a significant difference in the scores of successful group and the not-successful ones: $t=38.374, p=0.000$. Effect size calculated using Cohen's D test found large effect $d=3.878>0.8$.

These results suggest that successful enterprises differ significantly from the nonsuccessful ones in terms of the given set of personality traits (Tables 4 and 5).

\subsection{Identifying the personality factor(s)}

6.3.1 Factor analysis. Exploratory factor analysis was conducted over 11 trait items to understand underlying constructs within trait variables. As submitted above, in the research instrument, data in Part A measured demographic variables and data in Part C measured success level to group the samples. Hence, variables in Part A and Part C are not suitable for factor analysis as they are not going to give any meaningful conclusion, and they are not considered for factor analysis. Only the data in Part B, i.e. the 11 items of trait variables are considered for factor analysis to arrive at meaningful conclusion of identifying underlying construct(s). Keiser-Meyer-Olkin (KMO) measure of sampling adequacy was 0.954 , which is above the middle level of 0.5 and close to meritorious. KMO measures the quality of co-relations among variables to find suitability for a factor analysis. It compares the zero-order co-relations among the items with the partial co-relation among them. The score ranges from 0 and 1 . A score closure to 1 indicates strong co-relation among the items and small partial co-relation, whereas score closure to 0 indicates weak co-relation and higher partial co-relation. In the present case, a KMO of 0.954 indicates strong co-relation among items. As can be seen from the subsequent analysis wherein an inter-item co-relations test is run among the 11 trait items (Table 8) and found that there is strong and positive co-relation among the trait items. A high KMO score backed by high inter-item co-relations supports and substantiates each other. At the same time, it also establishes that the test is appropriate. Further, Bartlett's test of sphericity was significant $\left(\chi^{2}(55)=3,736.181\right.$, $p=0.000$ ) which justifies appropriateness of EFA. Orthogonal rotation with Varimax option and Kaiser normalization was accepted to find factor loading (Table 6).

The test result shows, all 11 items personality traits were loaded on one factor with eigenvalue $>1$, which explains cumulative variance of $68.78 \%$ and considered a good loading (cumulative variance explained is between $40 \%$ and $70 \%$ it is considered satisfactory. In case it is below $40 \%$, it is poor and above $70 \%$ is rare) (Table 7 ).

6.3.2 Labelling the factor: Entrepreneurs' Rraits Index. All 11 items of personality traits have been loaded onto one factor. This may be so because the traits seem to be strongly

\begin{tabular}{|c|c|c|c|c|c|c|}
\hline \multicolumn{6}{|c|}{ Group statistics } & \multirow{3}{*}{$\begin{array}{r}\text { Table } 4 . \\
\text { Group statistics } \\
\text { (personality traits) }\end{array}$} \\
\hline \multicolumn{2}{|c|}{ Outcome - successful or not successful } & $N$ & Mean & Std. deviation & Std. error mean & \\
\hline Personality traits & $\begin{array}{l}\text { Successful } \\
\text { Not successful }\end{array}$ & $\begin{array}{l}207 \\
189\end{array}$ & $\begin{array}{l}43.03 \\
25.93\end{array}$ & $\begin{array}{l}3.900 \\
4.864\end{array}$ & $\begin{array}{l}0.271 \\
0.354\end{array}$ & \\
\hline
\end{tabular}


XJM

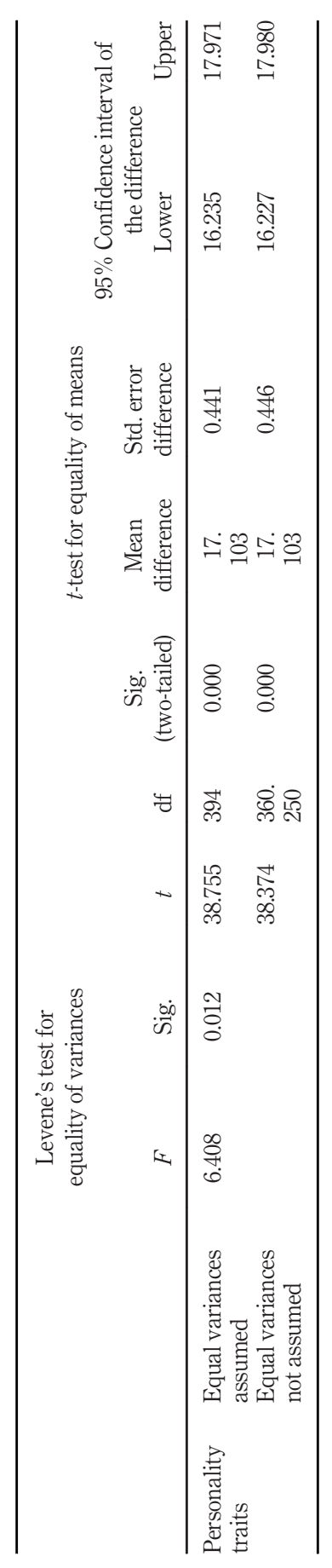

Table 5.

Independent samples test 
co-related with each other, hence contagious in nature. Therefore, a successful entrepreneur possessing one trait, is in all likelihood also possess other traits. It is like, the one, who is risk taking is also decisive and pro-active and by all chance accept changes and innovative. Reverse is true for the unsuccessful set of entrepreneurs which are typically identified with traits like risk averseness, indecisive, resistance to change and so on. Hence, we name this single factor as Entrepreneurs' Traits Index (ETI). This can be presented in a diagram as below (Figure 1).

To validate this, a co-relation test was run taking all 11 traits. Table 8 shows co-relation co-efficient among variables are positive and strong; hence, they are contagious and grouped under one factor.

\subsection{Cluster analysis - enterprise profiling based on traits}

To find how the entire group of successful and not-successful enterprises align themselves across these personality traits, cluster analysis technique was used. To determine optimum number of clusters, hierarchical agglomerative method with Ward's minimum variance was used. After looking into all solutions, finally two clusters were identified. The following table details the output of cluster analysis along with mean of cluster scores. Interpretation of the clusters was done keeping the criteria that variable wise group mean which is differentiated from the global mean by 0.5 standard deviation or more calculated from the raw, untransformed data (as suggested by Birley and Westhead, 1990)

Tables 9 and 10 show the distribution between the clusters across the traits.

Cluster 1 represents a group of 218 enterprises out of which $201(92 \%)$ were successful and $17(8 \%)$ were not successful. This group displayed high mean score across all 11 items of personality traits.

Cluster 2 consists of 178 enterprises out of which 172 (97\%) failed and only six (3\%) are successful. Members of this clusters scored lower than global mean across all parameters.

\begin{tabular}{llcr}
\hline Kaiser-Meyer-Olkin measure of sampling adequacy & & & \\
Bartlett's test of sphericity & Approx. Chi-square & 0.954 & Table 6. \\
& df & $3,736.181$ & KMO and Bartlett's \\
& Sig. & 55 & test \\
\hline
\end{tabular}

\begin{tabular}{|c|c|c|c|c|c|c|c|}
\hline \multirow[b]{2}{*}{ Component } & \multirow[b]{2}{*}{ Total } & \multicolumn{2}{|c|}{ Initial eigenvalues } & \multicolumn{3}{|c|}{ Extraction sums of squared loadings } & \\
\hline & & $\%$ of variance & Cumulative \% & Total & $\%$ of variance & Cumulative \% & \\
\hline 1 & 7.566 & 68.780 & 68.780 & 7.566 & 68.780 & 68.780 & \\
\hline 2 & 0.615 & 5.589 & 74.369 & & & & \\
\hline 3 & 0.545 & 4.959 & 79.328 & & & & \\
\hline 4 & 0.399 & 3.624 & 82.952 & & & & \\
\hline 5 & 0.378 & 3.435 & 86.387 & & & & \\
\hline 6 & 0.354 & 3.221 & 89.607 & & & & \\
\hline 7 & 0.299 & 2.720 & 92.327 & & & & \\
\hline 8 & 0.257 & 2.339 & 94.666 & & & & Table 7. \\
\hline 9 & 0.240 & 2.181 & 96.847 & & & & Total variance \\
\hline 10 & 0.219 & 1.993 & 98.840 & & & & explained \\
\hline 11 & 0.128 & 1.160 & 100.000 & & & & (personality traits) \\
\hline
\end{tabular}


The cluster analysis further reinforced the findings of factor analysis. Cluster 1 housed predominantly successful enterprises $(92 \%)$ with cluster mean higher than the global mean across all trait items. This implies that successful entrepreneurs displayed all traits in ETI while practicing the managerial tasks. However, small numbers of failed enterprises (17 nos., i.e. $8 \%$ ) in Cluster 1 also possessed similar personality traits but failed. This may be because of some other unidentified reasons. But the analysis establishes that with right attributes in place chances of success may be substantially high.

Cluster 2 housed $97 \%$ of the unsuccessful enterprises who scored substantially lower than the mean across all traits. This shows that the failed entrepreneurs lacked these leadership traits. Only $3 \%$ from Cluster 2 succeeded even though they lacked all traits. This can be treated as exceptions or success attributed to chance factors which may not sustain.

\begin{tabular}{llllllllllll}
\hline & PT1 & PT2 & PT3 & PT4 & PT5 & PT6 & PT7 & PT8 & PT9 & PT10 & PT11 \\
\hline PT1 & 1.000 & & & & & & & & & & \\
PT2 & 0.635 & 1.000 & & & & & & & & & \\
PT3 & 0.598 & 0.567 & 1.000 & & & & & & & & \\
PT4 & 0.696 & 0.597 & 0.575 & 1.000 & & & & & & & \\
PT5 & 0.632 & 0.605 & 0.664 & 0.691 & 1.000 & & & & & & \\
PT6 & 0.578 & 0.485 & 0.628 & 0.638 & 0.688 & 1.000 & & & & & \\
PT7 & 0.683 & 0.511 & 0.598 & 0.734 & 0.686 & 0.576 & 1.000 & & & & \\
PT8 & 0.589 & 0.539 & 0.655 & 0.624 & 0.675 & 0.632 & 0.650 & 1.000 & & & \\
PT9 & 0.643 & 0.568 & 0.685 & 0.692 & 0.747 & 0.703 & 0.705 & 0.696 & 1.000 & & \\
PT10 & 0.712 & 0.583 & 0.619 & 0.728 & 0.706 & 0.628 & 0.739 & 0.607 & 0.717 & 1.000 & \\
PT11 & 0.676 & 0.599 & 0.675 & 0.686 & 0.757 & 0.674 & 0.709 & 0.681 & 0.860 & 0.772 & 1.000 \\
\hline
\end{tabular}

Table 9.

\begin{tabular}{lcccc}
\hline & \multicolumn{2}{c}{ Cluster } & & \\
& 1 & 2 & Mean & SD \\
\hline PT1 & $4.29^{*}$ & $2.59^{*}$ & 3.53 & 1.11 \\
PT2 & $3.30^{*}$ & $1.76^{*}$ & 2.61 & 1.18 \\
PT3 & $3.93^{*}$ & $2.26^{*}$ & 3.18 & 1.13 \\
PT4 & $4.07^{*}$ & $2.25^{*}$ & 3.25 & 1.15 \\
PT5 & $4.10^{*}$ & $2.48^{*}$ & 3.37 & 0.87 \\
PT6 & $3.78^{*}$ & $2.56^{*}$ & 3.23 & 1.22 \\
PT7 & $4.12^{*}$ & $2.18^{*}$ & 3.25 & 0.85 \\
PT8 & $3.64^{*}$ & $2.40^{*}$ & 3.08 & 0.97 \\
PT9 & $3.78^{*}$ & $2.24^{*}$ & 3.09 & 1.15 \\
PT10 & $3.99^{*}$ & $2.17^{*}$ & 3.17 & 0.96 \\
PT11 & $3.81^{*}$ & $2.23^{*}$ & 3.10 &
\end{tabular}

Final cluster centres Note: *Score greater than 0.50 time standard deviation from global mean

Table 10.

Distribution between the clusters

\begin{tabular}{lccc}
\hline Particulars & Success & Non-successful & Total \\
\hline Cluster-1 & $201(92 \%)$ & $17(8 \%)$ & $218(100 \%)$ \\
Cluster-2 & $6(3 \%)$ & $172(97 \%)$ & $178(100 \%)$ \\
\hline
\end{tabular}


This indicates that chances of success are low when entrepreneur lacks positive personality traits (Tables 9 and 10).

\subsection{Regression analysis}

To ascertain, if personality traits could explain success, a simple linear regression was conducted. The predictor was the aggregate of all trait scores and the outcome was aggregate of success parameters. The predictor variable was found to be statistically significant $(\mathrm{B}=0.930, p=0.000$ ), indicating that for every one unit increase in independent variable (trait scores) the dependent variable (outcome) changed (+) 0.930 unit. The model explained approximately $86.60 \%$ of the variability $(\mathrm{R}$-squared $=0.866)($ Tables 11 and 12$)$.

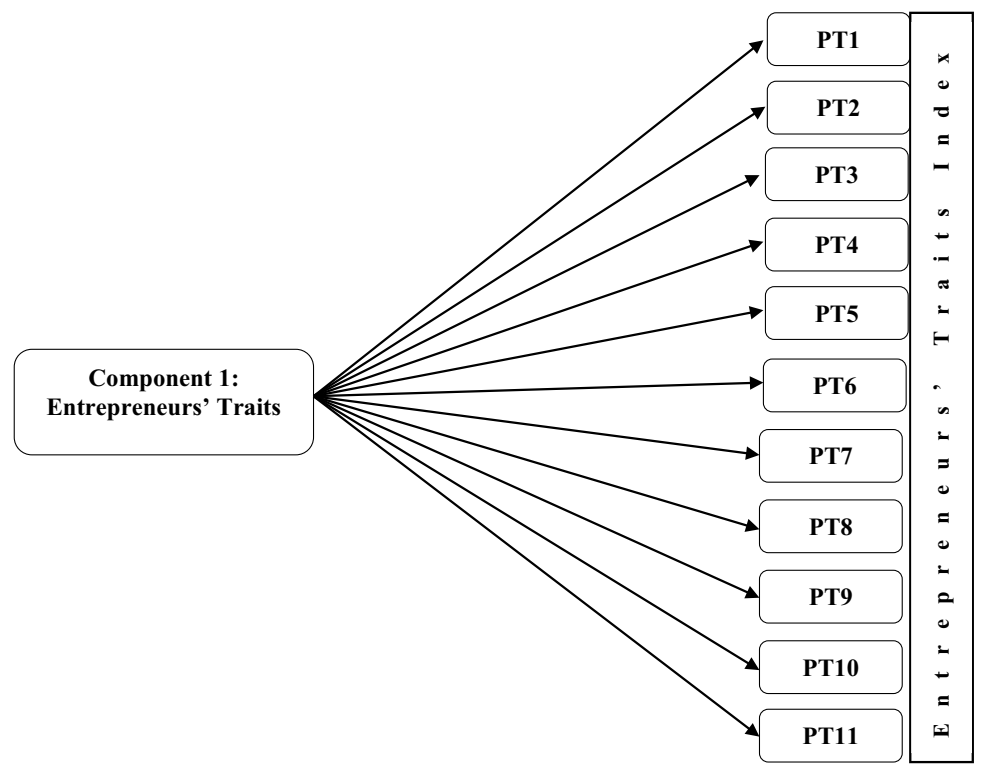

Figure 1.

Entrepreneurs' traits index

\begin{tabular}{lcccccccccc}
\hline & & & & \multicolumn{9}{c}{$\begin{array}{c}\text { Change } \\
\text { statistics }\end{array}$} \\
Model & $\mathrm{R}$ & R-square & $\begin{array}{c}\text { Adjusted } \\
\text { R-square }\end{array}$ & $\begin{array}{c}\text { Std. error of } \\
\text { the estimate }\end{array}$ & $\begin{array}{c}\text { R-square } \\
\text { change }\end{array}$ & F change & df1 & df2 & $\begin{array}{c}\text { Sig. F } \\
\text { change }\end{array}$ & Table 11. \\
\hline 1 & $0.930 \mathrm{a}$ & 0.866 & 0.865 & 3.770 & 0.866 & $2,536.845$ & 1 & 394 & 0.000 & Model summary \\
\hline
\end{tabular}

\begin{tabular}{|c|c|c|c|c|c|c|}
\hline \multirow[b]{2}{*}{ Model } & \multicolumn{2}{|c|}{ Unstandardized coefficients } & \multirow{2}{*}{$\begin{array}{c}\text { Standardized coefficients } \\
\text { Beta }\end{array}$} & \multirow{2}{*}{$t$} & \multirow[b]{2}{*}{ Sig. } & \\
\hline & $\mathrm{B}$ & Std. error & & & & \\
\hline $\begin{array}{ll}1 & \text { (Constant) } \\
& \text { Sum of all PT variable }\end{array}$ & $\begin{array}{c}-9.772 \\
0.994\end{array}$ & $\begin{array}{l}0.714 \\
0.020\end{array}$ & 0.930 & $\begin{array}{l}-13.692 \\
50.367\end{array}$ & $\begin{array}{l}0.000 \\
0.000\end{array}$ & $\begin{array}{l}\text { Table } 12 . \\
\text { Coefficients }\end{array}$ \\
\hline
\end{tabular}


If the findings of all statistical tests are analysed together, it gives a strong insight into role of personality traits in enterprise success. The test results show that there is positive and strong co-relation between the two. Traits are contagious having strong co-relation within them. A successful business leader possessing one trait is highly likely to possess others as well. Together they measure single underlying construct of several positive leadership traits which can be grouped under one factor and labelled as ETI. This is further substantiated by cluster analysis. Majority of successful entrepreneurs $(92 \%)$ are grouped under one cluster (Cluster 1) scoring high across all traits and the reverse in Cluster 2. This supports the findings of Beaver (2002) who argued that success factors and the circumstances to success vary from entrepreneur to entrepreneur. $t$-Test also supported this. Successful entrepreneurs are a different breed.

Finally, regression model underscores the importance of personality traits in explaining enterprise success. The model explains $84.3 \%$ of the success. This validates the previous findings of Miller (1983) and Lumpkin and Dess (1996) who viewed this as "entrepreneurial orientation" or that of Avolio (1999) and Judge and Piccolo (2004) who viewed these traits as "transformational leadership, and found them to be critical for enterprise success."

\section{Conclusion and implications}

The study finds relevance to multiple stakeholders. It has implication to entrepreneurs. Psychological studies emphasize that traits can be developed, practised and polished. Existing behaviours can be modified and new traits can be acquired. ETI comprising all such critical traits can be perused for augmenting managerial effectiveness.

It has takeaways for financial institutions like banks, who regularly evaluate enterprises for financial assistance. The test findings underscore the fact that a holistic evaluation of an enterprise is incomplete without considering the personality trait aspects. Enterprise actions are dependent upon entrepreneur's decisions, which in turn depend on his personality traits. Hence, along with analysis of financial aspects, behavioural aspects also need to be attended to in order to have a holistic view.

This study has potential to contribute to existing and future academic research. So far, enterprise studies focussed on aspects of the enterprise like products, process, finance, marketing, distribution and so on. Very scant focus was on psychological dimensions which is essentially behavioral traits of the entrepreneur. The findings indicate that it is a promising area of study.

However, the study has certain limitations. Personality traits are not the only factor influencing enterprise success. There are other factors like motivation, financial, management and external factors. A holistic study of traits along with other factors will help bring better insights. Bigger sample with larger geographical coverage of the study can make it broad based. The study is based on primary data. MSMEs are unorganised and hardly any published financial information is available in public domain. If they are also included, it may further improve generalizability of the findings. Further, if personality traits are analysed along with other success factors, it will bring understanding of direct and indirect role personality traits on enterprise success that may be the potential area for future research work.

\section{References}

Aragon-Correa, J.A., Garcia-Morales, V.J. and Cordon-Pozo, E. (2007), "Leadership and organizational learning's role on innovation and performance: lessons from Spain”, Industrial Marketing Management, Vol. 36, pp. 349-359. 
Avolio, B.J. (1999), Full Leadership Development: Building the Vital Forces in Organizations, Thousand Oaks, CA, Sage Publications.

Bass, B.M. and Avolio, B.J. (1997), Full-Range of Leadership Development: Manual for the Multifactor Leadership Questionnaire, Mind Garden, Palo Alto, CA.

Baum, J.R. and Locke, E.A. (2004), "The relationship of entrepreneurial traits, skill, and motivation to subsequent venture growth", Journal of Applied Psychology, Vol. 89 No. 4, pp. 587-598.

Bayarçelik, E.B. and Özşahin, M. (2014), "How entrepreneurial climate effects firm performance?", Procedia - Social and Behavioral Sciences, Vol. 150, pp. 823-833, doi: 10.1016/j.sbspro.2014.09.091.

Beaver, G. (2002), “The new business venture”, in Beaver, G. (Ed.), Small Business, Entrepreneurship and Enterprise Development, Pearson Education Ltd., p. 14.

Birley, S. and Westhead, P. (1990), "Private business sales environments in the United Kingdom", Journal of Business Venturing, Vol. 5 No. 6, pp. 349-373.

Boz, A. and Ergeneli, A. (2014), "Women entrepreneurs' personality characteristics and parents' parenting style profile in Turkey", Procedia - Social and Behavioral Sciences, Vol. 109, pp. 92-97.

Brandstätter, H. (1997), "Becoming an entrepreneur - a question of personality structure?", Journal of Economic Psychology, Vol. 18 Nos 2/3, pp. 157-177.

Caliendo, M., Fossen, F. and Kritikos, A.S. (2011), "Personality characteristics and the decision to become and stay self-employed”, IZA Discussion Paper No. 5566.

Chandler, G.N. and Lyon, D.W. (2001), "Issues of research design and construct measurement in entrepreneurship research: the past decade", Entrepreneurship Theory and Practice, Vol. 25 No. 4, pp. 101-113.

Chell, E. (1985), “The entrepreneurial personality: a few ghosts laid to rest?", International Small Business Journal: Researching Entrepreneurship, Vol. 3 No. 3, pp. 43-54.

Chittithaworn, C., Islam, M.A., Keawchana, T. and Yusuf, D.H.M. (2011), "Factors affecting business success of small and medium enterprises (SMEs) in Thailand", Asian Social Science, Vol. 7 No. 5 , pp. $180-190$.

Costa, P.T., Jr,. and McCrae, R.R. (1992), Revised NEO Personality Inventory (NEO-PI-R) and NEO Five Factor Inventory (NEO-FFI) Professional Manual, Odessa, FL, PAR.

Covin, J.G. and Slevin, D.P. (1991), "A conceptual model of entrepreneurship as firm behavior", Entrepreneurship Theory and Practice, Vol. 16 No. 1, pp. 7-25.

Epstein, S. and O'Brien, E. (1985), "The person-situation debate in historical and current perspective", Psychological Bulletin, Vol. 98 No. 3, pp. 513-537.

Frese, M., Brantjes, A. and Hoorn, R. (2002), "Psychological success factors of small scale businesses in Namibia: the roles of strategy process, entrepreneurial orientation and the environment", Journal of Developmental Entrepreneurship, Vol. 7 No. 3, pp. 259-282.

Gartner, W.B. (1988), "Who is an entrepreneur? Is the wrong question", Entrepreneurship Theory and Practice, Vol. 13 No. 4, pp. 47-68.

Gull, N., Asghar, M., Ahmed, Q.A., Muhammad, A.R., Jameel, A.S. and Ali, S.E. (2021), “Entrepreneurial orientation and international performance of born global firms: the mediating role of entrepreneurial competencies", Vilakshan-XIMB Journal of Management.

Gumusluoglu, L. and İlsev, A. (2009), "Transformational leadership, creativity, and organizational innovation”, Journal of Business Research, Vol. 62 No. 4, pp. 461-473.

Jaroliya, D. and Gyanchandani, R. (2021), "Transformational leadership style: a boost or hindrance to team performance in IT sector", Vilakshan-XIMB Journal of Management.

Judge, T.A. and Piccolo, R.F. (2004), "Transformational and transactional leadership: a meta-analytic test of their relative validity", Journal of Applied Psychology, Vol. 89 No. 5, pp. 755-768. 
Kets De Vries, M. (1977), “The entrepreneurial personality: a person at the crossroads”, Journal of Management Studies, Vol. 14 No. 1, pp. 34-57.

Küçük, O. (2005), "Girişimcilik ve küçük işletme yönetimi, seçkin yayınc1lı, Ankara 2ed.sector: a Canadian firm-level analysis", Technovation, Vol. 3, pp. 655-665.

Kumbul Guler, B. and Tinar, M. (2009), "Measuring the entrepreneurial level of the businessmen: the relationship between personal traits and entrepreneurial level", Ege Akademik Bakis (Ege Academic Review), Vol. 9 No. 1, pp. 95-111, doi: 10.21121/eab.2009119733.

Lather, A.S., Jain, V.K., Jain, S. and Vikas, S. (2009), "Leadership styles in relation to conflict resolution modes: a study of Delhi Jal Board (DJB)", Vilakshan: The XIMB Journal of Management, Vol. 6 No. 1.

Lumpkin, G.T. and Dess, G.G. (1996), "Clarifying the entrepreneurial orientation construct and linking it to performance", The Academy of Management Review, Vol. 21 No. 1, pp. 135-172.

McCrae, R.R. and Costa, P.T. Jr (2003), Personality in Adulthood: A Five-Factor Theory Perspective, New York, NY, Guilford Press.

Miller, D. (1983), "The correlates of entrepreneurship in three types of firms", Management Science, Vol. 29 No. 7, pp. 770-791.

Parks-Leduc, L. Feldman, G. and Bardi, A. (2014), "Personality traits and personal values: a meta-analysis", Personality and Social Psychology Review, Vol. 19 No. 1, pp. 3-29, doi: 10.1177/1088868314538548.

Rauch, A. and Frese, M. (2007), "Born to be an entrepreneur? Revisiting the personality approach to entrepreneurship", in Baum, J.R., Frese, M. and Baron, R.A. (Eds), The Psychology of Entrepreneurship, Mahwah, NJ, Erlbaum, pp. 41-65.

Robinson, R.B., Stimpson, D.V., Huefner, J.C. and Hunt, H.K. (1991), "An attitude approach to the prediction of entrepreneurship”, Entrepreneurship Theory and Practice, Vol. 15 No. 1, pp. 13-31.

Say, J.B. (1971), “A treatise on political economy or the production”, Distribution and Consumption of Wealth, A.M. Kelley Publishers, New York, NY, First edition 1803.

Schmitt-Rodermund, E. (2004), "Pathways to successful entrepreneurship: parenting, personality, early entrepreneurial competence, and interests", Journal of Vocational Behavior, Vol. 65 No. 3, pp. 498-518.

Schumpeter, J.A. (1934), "The Theory of Economic Development: An Inquiry into Profits, Capital, Credit, Interest and the Business Cycle, Cambridge, Harvard University Press.

Subramaniam, M. and Youndt, M.A. (2005), "The influence of intellectual capital of the types of innovative capabilities", Academy of Management Journal, Vol. 48 No. 3, pp. 450-463.

Varadarajan, P.R. and Ramanujam, V. (1986), "Diversification and performance: a re-examination using a new two-dimensional conceptualization of diversity in firms", Academy of Management Journal, Vol. 30, pp. 380-393.

Zhao, H. and Seibert, S.E. (2006), "The Big-Five personality dimensions and entrepreneurial status: a meta-analysis review", Journal of Applied Psychology, Vol. 91 No. 2, pp. 259-271.

Zikmund, W.G., Barry, J.B., Barry, J.C., Adhikari, A. and Griffin, M. (2017), "Business research methodsa South-Asian perspective, cengage learning, original edition 2010", South Western Cengage Learning, ISBN-13: 978-81-315-2036-9.

\section{Further reading}

McCrae, R.R. and Costa, P.T. Jr (1997), "Personality trait structure as a human universal", American Psychologist, Vol. 52 No. 5, pp. 509-516.

\section{About the authors}

Sthitaprajnya Pattanayak is pursuing $\mathrm{PhD}$ in Management from Assam Rajiv Gandhi University of Co-operative Management (ARGUCOM), Sivasagar, Assam. By profession, he is a banker and works in a commercial bank in India. He has over 19 years of experience in commercial banking in the areas 
of MSME advances, credit appraisal, operations and general banking. Other than this, he has keen research interest in enterprise studies, management and finance. Sthitaprajnya Pattanayak is the corresponding author and can be contacted at: hellospp@gmail.com

Prof (Dr) Munindra Kakati is a Professor of Finance, and presently Vice Chancellor of Assam Rajiv Gandhi University of Cooperative Management (ARGUCOM), Sivasagar. He is a distinguished academician and earlier, served as the Dean, Faculty of Management, Gauhati University, Guwahati. He is an alumnus of BITS (Pilani) and Gauhati University. He has several publications to his credit in national and international journals in the areas of management, enterprise studies, marketing and finance.

For instructions on how to order reprints of this article, please visit our website: www.emeraldgrouppublishing.com/licensing/reprints.htm Or contact us for further details: permissions@emeraldinsight.com 